\title{
ISTOTA PRZESTĘPSTW INDYWIDUALNYCH
}

Pojęcie „przestępstwa indywidualne” pojawia się zawsze, gdy w jakimkolwiek przedmiotowym opracowaniu przestępstwa katalogowane sa według różnorodnych klasyfikacji. Tym bardziej więc musi zdumiewać występujący $\mathrm{w}$ doktrynie prawa karnego pewien niedostatek opracowań dotyczących istoty tego rodzaju czynów zabronionych. Celem autora jest zatem bliższe przyjrzenie się przedstawianym dotychczas w doktrynie koncepcjom i definicjom przestępstwa indywidualnego w celu ich wzajemnego skonfrontowania oraz sformułowania na ich podstawie katalogu najważniejszych cech, jakie posiadaja przestępstwa indywidualne, co powinno wzbogacić dorobek karnistyki w tym zakresie.

Niewielka ilość prac poświęconych tej tematyce może jednak wynikać przede wszystkim z faktu, że mamy tu do czynienia z pojęciem, którego założenia konstrukcyjne oparte sa przede wszystkim na często sprzecznych z soba w pewnym zakresie opiniach doktryny prawa karnego materialnego ${ }^{1}$. Watpliwości związane $\mathrm{z}$ definitywnym ustaleniem istoty i cech przestępstw indywidualnych pogłębia fakt, że w Kodeksie karnym nie znajdziemy żadnej definicji przestępstwa indywidualnego. Czy też, mówiąc precyzyjniej, nie znajdziemy tam bezpośredniego wskazania, że jakiś przepis stanowi taką definicję. Jednak niektórzy ${ }^{2}$ uważaja, że taką definicję przestępstwa indywidualnego tworzy przepis regulujący szczególne właściwości odpowiedzialności ekstraneusów za współdziałanie przy przestępstwie indywidualnym, a więc art. 21 $\S 2$ k.k., o następującym brzmieniu: „Jeżeli okoliczność osobista dotycząca sprawcy, wpływająca chociażby tylko na wyższą karalność, stanowi znamię czynu zabronionego, współdziałający podlega odpowiedzialności karnej przewidzianej za ten czyn zabroniony, gdy o tej okoliczności wiedział, chociażby go nie dotyczyła". Przepis ten jednak nie odnosi się tylko do przestępstw indywidualnych, dotyczy bowiem wszystkich przestępstw, w których występuje

1 Dodać należy, że opinie te nie zawsze są ze sobą zgodne odnośnie do nawet tak fundamentalnej kwestii, jaką jest celowość wyróżniania takich przestępstw. Wyróżnianie przestępstw indywidualnych, choć tradycyjne w doktrynie, nie przez wszystkich jej przedstawicieli było akceptowane. Błędem byłoby chyba zignorowanie poniższej wypowiedzi Z. Łubkowskiego: „dzięki wyodrębnianiu przestępstw indywidualnych, jako swoistej kategorii, odmiennie zupełnie traktowanej, wprowadzimy do K.K. niejasność i kazuistykę, wówczas, gdy ma on na celu zerwanie z kazuistyką" (idem, Podżeganie i pomocnictwo przy przestepstwach t. zw. indywidualnych, „Głos Sądownictwa” 1936, s. 947).

${ }^{2}$ Np. S. Strycharz, Podżeganie i pomocnictwo do przestepstw indywidualnych, „Nowe Prawo” 1971 , nr 1, s. 47. 
podmiot typizowany przez szczególne właściwości, a więc regulacja ta będzie dotyczyć oprócz przestępstw indywidualnych także np. zabójstwa w afekcie. Trudno więc uznać, że przepis ten stanowi definicję przestępstwa indywidualnego ${ }^{3}$.

Przed przejściem do sedna omawianego zagadnienia, na samym wstępie należy poczynić niezbędne ustalenia terminologiczne. Chociaż w opracowaniu tym posługuje się pojęciem „przestępstwo indywidualne”, to nieodzowne wydaje mi się zaznaczenie, że ten powszechnie używany termin nie jest w pełni precyzyjny. Bardziej adekwatne byłoby używanie określeń „indywidualny” i „powszechny czyn zabroniony”, gdyż istotą tych pojęć jest to, czy w sytuacji ograniczonego zakresu adresatów normy sankcjonowanej zrealizowano znamiona typu czynu zabronionego, a nie to, czy sprawca popełnił przestępstwo, skoro znamiona danego typu czynu zabronionego moga przecież być realizowane niezależnie od np. wystapienia winy po stronie sprawcy (jak jest to choćby w przypadku niepoczytalności sprawcy). Dlatego pojęcie „przestępstwo indywidualne" trudno uznać za dostatecznie precyzyjne, jest ono jedynie kategorią wtórną wobec pojęcia „indywidualny czyn zabroniony”. Jeżeli więc w dalszej części pracy będę się posługiwał mimo wszystko terminem „przestępstwo indywidualne” czy też „przestępstwo powszechne”, to jedynie po to, aby uniknać chaosu terminologicznego, gdyż takimi właśnie określeniami posługuje się większość autorów, których poglądy będę przywoływał. Dodać też należy, że samo używanie przymiotnika „indywidualny” w odniesieniu do omawianej w tym miejscu grupy czynów jest czasami kwestionowane, gdyż w doktrynie wskazuje się niekiedy, iż bardziej adekwatne byłoby posługiwanie się pojęciem przestępstw (czynów zabronionych) „o zawężonym kręgu sprawców”5.

Płaszczyzna, na której dokonuje się wyszczególnienie przestępstwa indywidualnego, jest płaszczyzna ustawowych znamion, konkretnie znamienia podmiotu 6 , które należy do zakresu zastosowania normy sankcjonowanej i określa, kto może być sprawcą czynu zabronionego. W przypadku przestępstw powszechnych (delicta communia) podmiotem tym może być każdy ${ }^{7}$,

${ }^{3}$ Zdaniem autora, nie można bowiem przejść obojętnie wobec faktu, że art. 21 § 2 k.k. w ogóle nie mówi o przestępstwach indywidualnych, odnosząc się natomiast do wszystkich czynów zabronionych, których znamieniem jest szczególna okoliczność osobista dotycząca sprawcy, wpływająca chociażby tylko na wyższą karalność. Przepis ten będzie więc obejmował wszystkie szczególne okoliczności tworzące typy przestępstw indywidualnych, ale dodatkowo także okoliczności osobiste, związane z osobą sprawcy, które nie mają konstytutywnego charakteru w zakresie przestępstw indywidualnych, jak np. motywacja sprawcy czy działanie pod wpływem silnego wzburzenia. Do okoliczności osobistych będących znamieniem czynu zabronionego będą bowiem należeć również znamiona strony podmiotowej (nie ulega bowiem wątpliwości, iż są one immanentnie związane właśnie z osobą sprawcy, którego dotycza, dlatego zaliczenie ich do grona okoliczności osobistych jest oczywiste). Art. $21 \S 2$ k.k. nie będzie się więc odnosił wyłącznie do przestępstw indywidualnych, ale także, wbrew twierdzeniom niektórych przedstawicieli doktryny, do tzw. przestępstw o szczególnym podmiotowym zabarwieniu (szerzej omówionych w dalszej części pracy).

${ }^{4}$ Ł. Pohl, Struktura normy sankcjonowanej $w$ prawie karnym. Zagadnienia ogólne, Poznań 2007, s. 29, przyp. 36.

${ }^{5}$ Szerzej odnośnie do uzasadnienia takiego stanowiska: W. Wolter, Nauka o przestęstwie, Warszawa 1973, s. 32-33.

${ }^{6}$ A nie strony podmiotowej, co wymaga zaznaczenia już w tej części opracowania.

${ }^{7} \mathrm{O}$ pewnej nieścisłości tego twierdzenia w dalszym ciąu pracy. 
w przypadku przestęstw indywidualnych (delicta propria) dyspozycja normy wymaga od sprawcy posiadania określonej właściwości i konstruuje typ przestępstwa w ten sposób, że tylko w razie posiadania tej właściwości określone w dyspozycji normy działanie sprawcy jest przestępstwem ${ }^{8}$. W przypadku przestępstw indywidualnych właściwych w systemie prawnym zakazuje się zachowania określonego rodzaju jedynie osobom posiadajacym szczególne kwalifikacje osobiste (szczególna właściwość sprawcy jest tutaj warunkiem karalności czynu). W przypadku przestępstw indy widualnych niewłaś ciwych w systemie prawnym znajdują się dwie normy: jedna - zakazujacca takiego zachowania jedynie osobom posiadajacym określone kwalifikacje osobiste i druga - zakazujacca zachowania tego typu jedynie osobom nieposiadającym takich osobistych kwalifikacji (przy czasami występującej jednoczesnej modyfikacji bądź doprecyzowaniu opisu znamion) ${ }^{9}$. Zachowanie to będzie jednak zawsze zachowaniem podlegajacym odpowiedzialności karnej, niezależnie od tego, kto je popełnia ${ }^{10}$. Szczególna cecha sprawcy nie decyduje więc o karalności czynu w ogóle, lecz o tym, jaką normę sankcjonowaną przekracza sprawca. Przepis typizujący typ modyfikowany pełni więc tutaj rolę przepisu modyfikującego zwężajacco w odniesieniu do klasy adresatów normy sankcjonowanej leżącej u podstaw powszechnego typu czynu zabronionego, wyrażonej $\mathrm{w}$ przepisie ten podstawowy typ określającym ${ }^{11}$. Występowanie przestępstw indywidualnych niewłaściwych jest więc uzależnione od występowania przestępstwa powszechnego, do którego się one odnoszą. W efekcie w przypadku przestępstw indywidualnych niewłaściwych w stosunku do przestępstw ogólnosprawczych następuje ograniczenie kręgu osób, które mogą popełnić dane przestępstwo.

W przypadku przestępstw indywidualnych niewłaściwych wyróżniamy typy uprzywilejowane i kwalifikowane. Podział ten jest uzależniony od stopnia społecznej szkodliwości czynu związanej z popełnieniem danego przestępstwa $^{12}$. W przypadku typów kwalifikowanych podmiot danego przestępstwa atakuje dobro prawnie chronione w sposób zasługujaccy na większe potępienie niż w przypadku typu podstawowego ze względu na więzy łączące go z przedmiotem przestępstwa - to on bowiem jest specjalnie powołany do tego, aby dbać o integralność tego dobra ${ }^{13}$. Z odwrotna sytuacją mamy do czynienia w przypadku przestępstw uprzywilejowanych, gdzie szczególna właściwość sprawcy powoduje, że naruszenie przez niego integralności dobra prawnie chronionego zasługuje na mniejszy stopień potępienia niż w przypadku sprawcy przestępstwa powszechnego.

${ }^{8}$ J. Waszczyński (red.), Prawo karne w zarysie. Nauka o ustawie karnej i przestęstwie, Łódź 1992, s. 115-116. Inne, choć nieco podobne ujęcie - np. J. Makarewicz, Bezkarność podżegania i pomocnictwa, „Przegląd Prawa i Administracji” 1934, s. 3 (,przestępstwo indywidualne zachodzi wszędzie tam, gdzie ustawa wyraźnie ogranicza odpowiedzialność sprawcy do osób, mających swoiste właściwości”).

${ }^{9}$ Ł. Pohl, Prawo karne. Wyktad części ogólnej, Warszawa 2012, s. 120-121.

${ }_{10}$ K. Buchała, A. Zoll, Polskie prawo karne, Warszawa 1995, s. 140.

${ }^{11}$ Szerzej: Ł. Pohl, Prawo karne..., s. 65-67 i 118-119.

${ }^{12}$ Zob. szerzej: W. Wróbel, A. Zoll, Polskie prawo karne. Część ogólna, Kraków 2013, s. $190-191$.

${ }^{13}$ S. Strycharz, op. cit., s. 51. 
Zawężenie kręgu podmiotów przy przestępstwach indywidualnych może mieć postać zarówno pozytywna, przez wyliczenie cech, które sa potrzebne, by być podmiotem danego przestępstwa, jak i negatywną, polegajaca na określeniu tego, jakich cech nie może mieć podmiot czynu zabronionego - w ten sposób z kręgu tych podmiotów wyeliminowujemy osoby, które te cechy posiadaja a wystapienie których to cech w odniesieniu do potencjalnego sprawcy ma charakter znamion negatywnych, uniemożliwiajacych mu przypisanie przestępstwa. Raz określamy więc podmioty zdatne, a raz niezdatne do popełnienia przestępstwa indywidualnego, co w efekcie czyni pozostałe osoby zdatnymi do popełnienia danego przestępstwa ${ }^{14}$.

Należy stanowczo stwierdzić, że na tle powyższych ustaleń nie do końca bronią się już, wyrażane dawniej w doktrynie poglądy, zgodnie z którymi przestępstwa indywidualne niewłaściwe to takie, „których sprawca może być każdy człowiek, a szczególne cechy osobiste wpływają jedynie na wyższa (przestępstwo kwalifikowane) lub niższą (przestępstwo uprzywilejowane) karalność czynu"15. To głównie takie poglądy doprowadziły do tego, że w odniesieniu do tej kategorii przestępstw w ich nazwie posługujemy się zwrotem „niewłaściwe”, gdyż w pewien sposób „prawdziwymi” przestępstwami miałyby być jedynie przestępstwa indywidualne określane jako „właściwe”. Abstrahując od tego, czy takie nazewnictwo ma swoje uzasadnienie, należy zauważyć, że rzeczony pogląd nie zasługuje na aprobatę ze względu na mylne utożsamianie z sobą czynności, której popełnienia zakazuje dane przestępstwo, z samym przestępstwem. Czynność wyrażana przez znamię czasownikowe typu podstawowego (powszechnego) i modyfikowanego (indywidualnego) rzeczywiście może być popełniona przez każdy podmiot, jednak przestępstwo w typie modyfikowanym może popełnić jedynie podmiot dysponujący szczególnymi cechami. Samo znamię czasownikowe nie wyczerpuje przecież wszystkich znamion przestępstwa. Dodać należy, że właśnie w powyższym poglądzie znajduje się uzasadnienie twierdzenia Władysława Woltera, że nie jest możliwe podżeganie i pomocnictwo ze strony ekstraneusów do przestępstw indywidualnych właściwych, ale jest możliwe ono w odniesieniu do przestępstw indywidualnych niewłaściwych, skoro mogą być one popełniane przez każdego. Powyższy pogląd nie broni się jednak po wykazaniu wskazanego powyżej błędu zawartego w tezie, że przestępstwa indywidualne niewłaściwe mogą być popełnione przez każdy podmiot.

Z wyżej wskazanych ustaleń wynika to, że normy sankcjonowane wyrażajace zakaz popełniania tzw. przestępstw powszechnych nie zawsze odnosza się więc - wbrew powszechnie wyrażanemu w karnistyce przekonaniu - do wszystkich ludzi ${ }^{16}$. Dzieje się to jedynie wtedy, gdy żaden przepis modyfi-

${ }^{14}$ W. Wolter, Nauka..., s. 34.

${ }^{15} \mathrm{~W}$. Wolter, Podżeganie i pomocnictwo do przestępstw kwalifikowanych, „Wojskowy Przegląd Prawniczy” 1974, nr 1, s. 125. Wcześniej podobne poglądy wyrażał J. Makarewicz, który posługiwał się kategoria „przestępstw ściśle indywidualnych” i dlatego np. nie uważał za przestępstwo indywidualne dzieciobójstwa (J. Makarewicz, op. cit., s. 4, przyp. 4).

${ }_{16}$ Przez ogół ludzi rozumiemy tutaj wszystkich ludzi, niezależnie od ich wieku lub niepoczytalności, które są uważane za czynniki warunkujące odpowiedzialność karna, a nie zdolność do wypełnienia znamion czynu zabronionego (czyli osoba niepoczytalna przekracza normę 
kujący nie wpływa na klasę adresatów normy sankcjonowanej wyrażającej zakaz popełniania przestępstw o charakterze powszechnym. Jeżeli taki przepis modyfikujacy występuje, mamy do czynienia z podziałem na intraneusów, którzy są adresatami normy sankcjonowanej zakazującej popełnienia czynu stypizowanego przez przepis modyfikujacy, i ekstraneusów, którzy nie moga być sprawcami tych czynów ze względu na brak wymaganej cechy. Intraneusów znamionują wskazane w tekście przepisów prawnych specjalne wyróżniające ich z ogółu ludności kwalifikacje osobiste, ze względu na które następuje zmiana zasad ich odpowiedzialności przez utworzenie przepisów modyfikujących. Kwalifikacji tych nie posiadają adresaci normy zakazujacej popełnienia przestępstwa powszechnego i dlatego nazywamy ich ekstraneusami. Przestępstwa powszechne nie są więc takimi, które odnoszą się do każdego człowieka, a jedynie do osób nieposiadających szczególnych cech o sobistych (tylko niekiedy będzie się to odnosiło do ogółu ludzi) ${ }^{17}$. W przeciwnym razie doszłoby do sytuacji, że typy podstawowe czynów zabronionych, jeżeli towarzyszy im typ modyfikowany o ograniczonym zakresie podmiotowym, należałoby uznać za przestępstwa indywidualne, ponieważ nie odnosza

sankcjonowana, lecz nie stosujemy do niej normy sankcjonującej). Por. Ł. Pohl, Prawo karne..., s. 121-130. Odmiennie: J. Śliwowski, Prawo karne, Warszawa 1975, s. 124.

${ }_{17}$ Trzeba jednak w tym miejscu zaznaczyć, że ta koncepcja oparta jest na założeniu, iż wszystkie znamiona typu czynu zabronionego pod groźbą kary wyznaczają treść normy sankcjonowanej. Inaczej jest przy przyjęciu odmiennej koncepcji podziału znamion na te decydujące o bezprawności i te decydujące o karalności czynu - do tej drugiej grupy należałaby szczególna cecha podmiotu przestępstwa indywidualnego; zgodnie $\mathrm{z}$ tą koncepcją możliwe jest przekroczenie normy sankcjonowanej zakazującej przestępstwa indywidualnego również przez ekstraneusa, wobec którego w takim wypadku nie stosujemy jednak normy sankcjonującej. Sens art. $21 \S 2$ k.k. polegałby więc na poszerzeniu zakresu zastosowania normy sankcjonującej również do ekstraneusów: A. Zoll, O normie prawnej z punktu widzenia prawa karnego, „Krakowskie Studia Prawnicze” 1990, s. 8687; także R. Dębski, O teoretycznych podstawach regulacji wspótdziałania przestęnego $w$ Kodeksie karnym z 1997 r., „Studia Prawno-Ekonomiczne” 1998, s. 24, chociaż autor wyróżnia też sytuacje, gdy ekstraneus nie przekracza żadnej normy. Nawet jednak przy założeniu, że wszystkie znamiona typu czynu zabronionego pod groźbą kary wyznaczają treść normy sankcjonowanej, możliwa jest także odmienna interpretacja, zgodnie z którą norma zakazująca popełniania przestępstwa powszechnego odnosi się do również do intraneusów - zachodzi więc tutaj zbieg przepisów rzeczywisty, lecz nieuwzględniany w przepisach prawnych (lex specialis derogat legi generali). Koncepcja ta wymaga rozważenia, choć raczej należałoby ją odrzucić ze względu na to, że trudno zrozumieć, czemu intraneus, popełniając przestępstwo indywidualne niewłaściwe, czyli przekraczając normę sankcjonowaną zakazującą popełnienia tego przestępstwa indywidualnego, miałby jednocześnie przekraczać także drugą normę sankcjonowana zakazująca popełnienia przestępstwa powszechnego, skoro i tak nie będzie odpowiadał za jego popełnienie, a za popełnienie przestępstwa indywidualnego. Kolejną koncepcją jest rozwiązanie stworzone przez S. Lisockiego (Karalność podżegania i pomocnictwa do przestęstw indywidualnych w kodeksie karnym polskim, „Czasopismo Prawne i Ekonomiczne” 1938, s. 83-84), zgodnie z którym wszystkie normy prawne adresowane są do każdego człowieka (ze względu na spójność systemu prawnego), ale w przypadku przestępstw indywidualnych, niektórzy nie są w stanie ich popełnić ze względu na brak szczególnych właściwości. Konstrukcja stworzona przez Lisockiego nie zasługuje jednak na aprobatę z jednej prostej przyczyny - jeżeli wpisujemy w treść normy szczególne właściwości dotyczące podmiotu przestępstwa, które nie pozwalają na przekroczenie tej normy innym podmiotom, to przecież właśnie w ten sposób ograniczamy krag adresatów normy sankcjonowanej. Nie da się więc adresować normy do wszystkich, a jednocześnie sprawić, aby niektórzy nie mogli jej przekroczyć. 
się do wszystkich osób, skoro nie dotycza podmiotów przestępstwa indywidualnego niewłaściwego - mielibyśmy więc przy takim rozumowaniu do czynienia z dwoma przestępstwami indywidualnymi, jednym w typie modyfikowanym, drugim w typie podstawowym, skoro żadnego $\mathrm{z}$ nich nie moga popełnić wszyscy. Koncepcja ta wydaje się zaciemniać obraz sytuacji, dlatego lepiej przyjąć, że wyróżnikiem bytu przestępstw powszechnych jest nie powszechność sprawstwa, ale nieposiadanie przez ich sprawców specjalnych właściwości, które posiadaja sprawcy przestępstw indywidualnych. W przypadku przestępstw indywidualnych niewłaściwych podmiot przestępstwa powszechnego w typie podstawowym odnoszącego się do przestępstwa indywidualnego niewłaściwego będzie zakreślony w ten sposób, iż z grona wszystkich osób eliminujemy mniejszość cechująca się specyficznymi właściwościami, która ze względu na te właśnie właściwości może wypełnić znamiona przestępstwa indywidualnego niewłaściwego.

Z kolei Władysław Bugajski ${ }^{18}$ sformułował swego czasu tezę, że w przypadku przestępstw indywidualnych odmienność względem dobra prawnie chronionego polega na tym, że w przypadku każdego $\mathrm{z}$ tych przestępstw intraneus narusza swoim czynem w pierwszej kolejności szczególny obowiazek ciążący na nim z powodu szczególnego stosunku społecznego. Przestępstwa indywidualne polegałyby więc po prostu na niedopełnieniu obowiązku, któremu nie odpowiada żaden podmiot, oprócz sprawcy, a podstawowym dobrem prawnie chronionym, które jest tutaj naruszane, jest właśnie ów obowiązek. Natomiast w przypadku przestępstw powszechnych przekraczany jest jedynie bezpośrednio odpowiedni zakaz karny, co powoduje naruszenie jakiegoś dobra prawnie chronionego - nie jest bowiem wymagany żaden ekstraordynaryjny stosunek społeczny, aby naruszyć zdrowie i życie człowieka w przypadku zabójstwa ${ }^{19}$.

Koncepcja ta zasługiwałaby na uznanie, gdyby nie to, że nie uwzględnia ona faktu, iż trudno powiedzieć, aby szczególne właściwości wyróżniające podmiot przestępstwa indywidualnego stanowiły jednolitą grupę. Przykładowo Stanisław Strycharz ${ }^{20}$ dzieli je na:

a) Charakter pełnionej przez sprawcę funkcji w aparacie państwowym lub innym podmiocie (przestępstwa związane $\mathrm{z}$ byciem funkcjonariuszem publicznym albo popełniane w związku z pełnieniem funkcji publicznej);

b) Pewien szczególny stosunek do osoby, której dobro prawnie chronione zostało naruszone lub zagrożone (tym szczególnym stosunkiem jest pokrewieństwo z ofiara, pozostawanie w związku małżeńskim, istnienie obowiązku opieki wobec pokrzywdzonego);

c) Kryjący się we właściwościach sprawcy pewien stan zagrożenia dla chronionych prawem interesów - na sprawcę jest wtedy nałożony obowiazek takiego zachowania się, aby uniknąć stworzenia stanu zagrożenia dla

\footnotetext{
${ }^{18}$ W. Bugajski, O przestępstwach indywidualnych, „Państwo i Prawo” 1965, z. 5-6, s. 833-834.

${ }_{19}$ Poza wyjątkową sytuacja, jaką jest zabójstwo popełniane przez zaniechanie, co wynika z art. 2 k.k.

${ }^{20}$ S. Strycharz, op. cit., s. 50-51.
} 
innych osób (bycie zarażonym chorobą weneryczną lub wirusem HIV bądź składanie zeznań).

Koncepcja Bugajskiego nie odnosi się więc niewątpliwie do kategorii c, która grupuje okoliczności o charakterze faktycznym, niewynikające z żadnego szczególnego stosunku społecznego, dlatego też stworzone przez niego rozwiązanie trudno uznać za uniwersalnie tłumaczące problem przestępstw indywidualnych. Jego teza jest w pewien sposób słuszna, ale jedynie w odniesieniu do przestępstw indywidualnych wyróżnianych ze względu na szczególny obowiązek ciążący na ich podmiocie (grupy a i b). Nie zawsze jednak do szczególnych właściwości wyróżniających sprawcę przestępstwa indywidualnego należy obowiązek szczególnego zachowania się, o czym oprócz przywołanych wyżej przestępstw, popełnianych przez stworzenie stanu zagrożenia dla prawnie chronionych interesów, świadczy choćby przykład przestępstw indywidualnych niewłaściwych uprzywilejowanych, w przypadku których nie występuje po stronie sprawcy żaden szczególny obowiązek decydujący o jego karalności.

Przedstawiciele doktryny, dotykajac w swych pracach problematyki przestępstw indywidualnych, zazwyczaj zaznaczaja, że wszystkie powyższe uwagi dotycza jedynie tzw. przestępstw indywidualnych co do sprawcy, a nie odnoszą się do (wyróżnianych przez niektórych karnistów) przestępstw indywidualnych co do czynu. Przestępstwa z tej drugiej grupy nazywane są także przestępstwami własnoręcznymi lub sytuacyjnymi. Moga być popełnione przez każdego, wymagaja jednak działania w ściśle określonej sytuacji - inaczej nie można ich popełnić. W ich przypadku, zdaniem niektórych ${ }^{21}$, nie jest możliwe współsprawstwo w ich popełnieniu. Jerzy Śliwowski jako przykłady takich przestępstw przytacza składanie fałszywych zeznań i samouwolnienie się $^{22}$. Uważa on, że takie przestępstwa ze swej natury są przestępstwami ogólnosprawczymi, tyle tylko, że dla ich popełnienia ustawa wymaga zaistnienia szczególnej sytuacji, w której musi się znaleźć sprawca. Jednak podmiotem tego przestępstwa może być każdy. Stwierdza tė̇ on, że wyodrębnienie tych przestępstw ma jedynie znaczenie teoretyczne ${ }^{23}$ i wynika z niemieckiej nauki o stanie faktycznym przestępstwa (die Lehre vom Tatbestand). Oba te rodzaje przestępstw indywidualnych łączy to, że ograniczają krag personalny sprawców - w przypadku przestępstw indywidualnych co do sprawcy ograniczenie zachodzi na płaszczyźnie subiektywnej, a w przypadku przestępstw własnoręcznych - obiektywnej ${ }^{24}$. Pomiędzy tymi dwiema grupami znajdują się przestępstwa popełniane przez żołnierzy, gdyż co prawda może je popełnić tylko osoba wojskowa, jednak ze względu na powszechność służby wojskowej może nią być niemal każdy ${ }^{25}$.

${ }^{21}$ H. Rajzman, Zarys wykładu prawa karnego, Rzeszów 1968, s. 174.

22 J. Śliwowski, op. cit., s. 125.

${ }^{23} \mathrm{Z}$ którą to tezą trudno się zgodzić dlatego, że ustalenia te mogą oddziaływać przecież na zakres zastosowania art. 21 k.k., a więc wymiernie wpływać na odpowiedzialność ekstraneusów współdziałających z intraneusami.

24 J. Śliwowski, op. cit., s. 125.

25 Ibidem, s. 126-127. 
Już jednak wcześniej zauważył słusznie Leon Tyszkiewicz ${ }^{26}$, że bardzo często nie da się odróżnić przestępstw indywidualnych co do sprawcy i indywidualnych co do czynu, o czym przekonuje choćby przykład przestępstwa składania fałszywych zeznać, bo czy fakt składania fałszywych zeznań w charakterze świadka to cecha podmiotu, czy też określona sytuacja, w której się on znajduje? Autor całkowicie zasadnie konstatuje więc, iż „przestępstwa własnoręczne można sprowadzić do przestępstw indywidualnych, a przestępstwa indywidualne do własnoręcznych, gdyż chyba podział, o którym mowa, powstał na tle nieistotnych rozbieżności w formułowaniu poszczególnych przepisów”27, głównie mając tutaj na myśli określenie podmiotu, które raz wydaje się bardziej wskazywać na jego cechy, a następnym razem na sytuację, w jakiej on działa.

Konstrukcja przestępstwa indywidualnego co do czynu została zapożyczona z nauki niemieckiej, głównie w celu ograniczenia zakresu zastosowania sprawstwa pośredniego ${ }^{28}$. Na gruncie nauki polskiej jej wyróżnianie nie wydaje się jednak niezbędne, oczywiście ze względu na brak w polskim systemie prawa karnego miejsca dla sprawstwa pośredniego. Dodać należy, że odrębny charakter przestępstw własnoręcznych mogłaby uzasadniać teza, iż nie jest w ich przypadku możliwe współsprawstwo, co miałoby czynić je wyjątkowymi na tle innych rodzajów przestępstw. Jednak powyższa teza nie wydaje się uzasadniona, skoro np. w przypadku samouwolnienia się z łatwością można sobie wyobrazić sytuację, gdy dwaj więźniowie wspólnie i w porozumieniu dokonuja ucieczki z więzienia. Kolejnym przykładem zaprzeczającym tezie, że przestępstwa własnoręczne nie moga być dokonywane we współsprawstwie, jest złożenie fałszywej opinii przez zespół biegłych. Zdaniem Andrzeja Wąska przy takich przestępstwach mamy do czynienia po prostu z pewnym ograniczeniem ujmowania instytucji współsprawstwa, a nie z całkowitym zaprzeczeniem temu, że te przestępstwa można w ten sposób popełniće ${ }^{29}$.

Wyróżniane są także w doktrynie tzw. przestępstwa o szczególnym podmiotowym zabarwieniu, czyli - jak chcą inni - „przestępstwa o bliżej określonej stronie podmiotowej”. W przypadku tego rodzaju przestępstw (klasycznym przykładem byłoby zabójstwo pod wpływem afektu) mamy do czynienia z bliższym doprecyzowaniem nie podmiotu, ale strony podmiotowej. Nie da się jednak ukryć, że cechy strony podmiotowej warunkuja przecież podmiot czynu zabronionego, a to w naturalny sposób prowadzi nas do problemu odróżnienia tych przestępstw od przestępstw indywidualnych sensu stricto. Elementem wspólnym dla obu tych grup przestępstw są występujące w obu przypadkach specyficzne właściwości osobiste ${ }^{30}$. Różnica polega jednak na tym, że przy przestępstwach o szczególnym podmiotowym zabarwieniu, okoliczności te maja charakter subiektywny, związany z przeżyciami psychicznymi sprawcy, natomiast przy przestępstwach indywidualnych muszą one wystapić w sposób

${ }^{26}$ L. Tyszkiewicz, Wspótdziałanie przestęne $i$ główne pojęcia z nim zwiazane w polskim prawie karnym, Poznań 1964, s. 134-136.

27 Ibidem, s. 135.

28 Ibidem, s. 134-136.

29 A. Wąsek, Wspótsprawstwo w polskim prawie karnym, Warszawa 1977, s. 150-151.

${ }^{30}$ L. Tyszkiewicz, op. cit., s. 136-137. 
obiektywny. Podobnie jak w przypadku przestępstw indywidualnych, należy zauważyć, iż również tutaj występuje problem podżegania do ich popełnienia przez osobę, u której nie występują te subiektywne cechy osobiste. Na przykład: Czy może podżegać do zabójstwa w afekcie ktoś, kto nie posiada takiej cechy? I czy w takim przypadku można nadal mówić, że sprawca działa pod wpływem afektu, skoro działał pod wpływem namowy?

Często wyróżniano też grupy przestępstw podobnych do przestępstw indywidualnych. I tak Juliusz Makarewicz wyróżniał pojęcie przestępstwa zawodowego (grupowego) - obejmowało przestępstwa, w którym warunkiem odpowiedzialności sprawcy była przynależność do danej grupy lub bycie reprezentantem jakiegoś zawodu. Dla Makarewicza przestępstwa indywidualne były bowiem przestępstwami indywidualnymi w ścisłym znaczeniu tego słowa, odnosiły się jedynie do posiadającego odpowiednie kwalifikacje sprawcy $^{31}$. Jego zdaniem, przykładowo, przestępstwem indywidualnym nie jest dzieciobójstwo ${ }^{32}$, które stanowi jedynie uprzywilejowaną postać zabójstwa (podobnie jak zabójstwo eutanatyczne). Zgodnie z tym stanowiskiem jedynie przestępstwa indywidualne właściwe można uznawać za przestępstwa indywidualne. Trudno tu jednak nie zwrócić uwagi na pewną niespójność poglądów autora, skoro parę stron dalej, niż miejsce, gdzie znajduje się przywołany cytat, pisze on: „istotą przestępstwa indywidualnego jest to, że sprawca należy do jakiejśs odrębnej grupy, choćby nawet bardzo licznej"33. Problem pojawia się tutaj szczególnie wtedy, gdy mówimy o przestępstwach, które mogą być popełnione wyłącznie przez obywatela polskiego (np. art. 141 obecnego k.k.). Czy skoro ograniczono klasę adresatów normy sankcjonowanej tych typów czynów zabronionych jedynie do obywateli polskich, to mamy tutaj do czynienia z przestępstwem indywidualnym, czy też nie, skoro jest to grupa podmiotów o niezwykle dużej liczebności?

Trzeba jednak zauważyć, że nie są to jedyne klasyfikacje przestępstwa indywidualnego. Świadczy to o tym, jak duża jest różnorodność czynów zabronionych zaliczanych do tej grupy przestępstw ${ }^{34}$. O tym, jak skomplikowana jest sytuacja, świadczyć może klasyfikacja stworzona przez Jerzego Bafię $e^{35}$, który uwzględniając rożne rodzaje przestępstw wyróżnianych ze względu na swój podmiot, stworzył następującą klasyfikację podmiotów czynu zabronionego:

1) podmiot ogólnie sformułowany, czyli określany przez ustawę zaimkiem „kto”;

2) podmiot nazywany bezpośrednio, np. funkcjonariusz publiczny czy matka, charakterystyczny dla przestępstw indywidualnych;

31 J. Makarewicz, op. cit., s. 4-5.

$32 \mathrm{O}$ sporach związanych z tym, czy faktycznie jest to przestępstwo indywidualne: M. Tarnawski, Zabójstwo uprzywilejowane w ujęciu polskiego prawa karnego, Poznań 1981, s. 104-106.

33 J. Makarewicz, op. cit., s. 12.

34 „Bez wątpienia przestępstwa indywidualne nie są tworzone na podstawie jednej tylko metody i wyodrębniane w oparciu o jedno kryterium [...] mają zróżnicowany charakter i zróżnicowane podstawy" (R. Dębski, op. cit., s. 24-25), które to stwierdzenie zdecydowanie należy mieć na uwadze, rozważając wszelkie kwestie związane z przestępstwami indywidualnymi.

35 J. Bafia, Polskie prawo karne, Warszawa 1989, s. 137-139. 
3) podmiot nazywany pośrednio, a więc nie za pomoca indywidualizujacego rzeczownika; indywidualizacja dokonuje się tutaj za pomocą opisu funkcji, jaką spełnia podmiot (np. w art. 296 k.k.: „kto, będąc obowiązanym [...]”);

4) podmiot określony przez sytuację: jego właściwości ze względu na sytuację, w jakiej się znajduje, predestynują go do popełnienia czynu zabronionego (np. bigamista, którym może zostać jedynie osoba pozostająca w związku małżeńskim; innym przykładem jest osoba popełniająca czyn zabroniony pod wpływem alkoholu);

5) podmiot określony przez motywację czynu: podmiot wyznaczony jest tutaj kierunkowym motywem, np. działa „w celu osiagnięcia korzyści majątkowej"; bez tego kierunkowego nastawienia zachowanie podmiotu nie będzie bezprawne;

6) podmiot kryminologicznie naznaczony - podmiot bądź o cechach określonej aktywności przestępczej (osoba, która uczyniła sobie z przestępstwa stałe źródło dochodu ${ }^{36}$ ) bądź odgrywający bezpośrednią rolę kryminogenną (podżegacz lub osoba wzywająca publicznie do popełnienia przestępstwa);

7) podmiot wieloosobowy, który występuje w takich typach przestępstwa, które nie mogą być popełnione przez jedną osobę (klasycznymi przykładami sa tutaj przestępstwa bójki, pobicia lub gwałtu zbiorowego).

Zgodnie z tą klasyfikacją do przestępstw indywidualnych należą podmioty sklasyfikowane w grupach 2, 3 i 4. Widać więc, że wśród przestępstw indywidualnych trudno wskazać jakaśs wspólną grupę cech, które w sposób zdecydowany wyróżniałyby je spośród innych grup przestępstw. Wszystko powyższe uświadamia, jak sądzę w sposób dobitny, jak bardzo niespójną grupą są przestępstwa określane mianem „indywidualnych”. W związku z tym trudno tutaj formułować pewne daleko idące uogólnienia dotyczące ich cech.

Wydaje się jednak, że światło na omawiany problem może rzucić próba spojrzenia na przestępstwa indywidualne pod kątem porównania $\mathrm{z}$ przestępstwami popełnianymi na skutek wprawienia się w stan nietrzeźwości ${ }^{37}$. W takich sytuacjach raczej nie mamy do czynienia z przestępstwami indywidualnymi, gdyż każdy człowiek jest w stanie wprawić się w stan nietrzeźwości - tak jak każdy może zabić innego człowieka. Gdybyśmy dopuścili do tego, że wprawienie się w stan nietrzeźwości to cecha szczególna, doprowadzilibyśmy do sytuacji, gdy każde przestępstwo byłoby indywidualne - cecha wyróżniająca przestępstwa indywidualne jest przecież właśnie to, że nie wszyscy obiektywnie moga popełnić dany czyn. Oczywiście trzeba zauważyć, że nawet $\mathrm{w}$ przypadku przestępstw raczej bezspornie klasyfikowanych jako powszechne, nie każdy będzie je w stanie popełnić, trudno bowiem przypuszczać, aby zabić człowieka mogła np. osoba znajdująca się w śpiączce. Faktyczna niemożność popełniania przestępstw wynika tutaj jednak z cech danej osoby, a nie z właściwości jakiegoś pojedynczego przestępstwa. Osoba niebędąca w stanie dokonać z przyczyn obiektywnych tego czynu zabronionego nie będzie bowiem mogła popełnić wszystkich przestępstw, a nie tylko jednego

36 Trzeba zaznaczyć, że obecnie uczynienie sobie z przestępstwa stałego źródła dochodu nie jest typizowane jako odrębne przestępstwo, jak było to w k.k. z 1969 r. (art. 215 § 2).

37 S. Strycharz, op. cit., s. 52. 
wybranego, w przeciwieństwie np. do osoby niebędącej żołnierzem, która nie może popełnić przestępstw z części wojskowej k.k., ale może popełnić wszystkie inne przestępstwa powszechne.

Cechą wyróżniającą grupę przestępstw określanych jako indywidualne, byłaby więc możność ich popełnienia przez wszystkie bądź tylko niektóre podmioty. Problem powstaje w związku z ocena momentu niemożności popełnienia przestępstwa indywidualnego - czy oceny tej należy dokonywać w tym momencie czasu, w jakim się znajdujemy, czy też powinniśmy uwzględniać również potencjalną możliwość uzyskania przez ekstraneusa w przyszłości cech, które predestynowałyby go do popełnienia przestępstwa indywidualnego? Przykładowo - czy możemy mówić o tym, że przestępstwo bigamii ma charakter przestępstwa indywidualnego, jeżeli każdy, kto nie pozostaje w związku małżeńskim, może w przyszłości taki związek zawrzeć i zaczać wtedy przynależeć do klasy adresatów normy sankcjonowanej zakazującej popełnienia tego przestępstwa? Wydaje się, że ograniczenia podmiotowe formułowane przez przestępstwa indywidualne należy odnosić do tego momentu w czasie, w którym obecnie się znajdujemy - jeżeli ktoś nie pozostaje w związku małżeńskim, nie może popełnić przestępstwa bigamii. Jeżeli mamy tutaj do czynienia z takim ograniczeniem, to przestępstwo to ma charakter indywidualny. Gdybyśmy natomiast ciężar problemu przesuwali na to, czy jakaś osoba może w przyszłości zacząć należeć do kręgu adresatów tego przestępstwa, w zbyt dużym stopniu opieralibyśmy się tutaj na przypuszczeniach dotyczących przykładowo tego, czy jest prawdopodobne, aby ktoś został w przyszłości funkcjonariuszem publicznym i mógł w ten sposób stać się potencjalnym podmiotem przestępstw popełnianych przez tę grupę osób. Musielibyśmy tutaj relatywizować nasze rozważania w odniesieniu do konkretnych osób, a mimo to i tak nie mielibyśmy pewności, czy okażą się one w przyszłości trafne. Ze względu na niemożliwość oceny tego, czy ktoś będzie mogło zostać podmiotem przestępstwa indywidualnego, wydaje się, iż lepiej odejść od takiego podejścia i skupić się jedynie na tym, czy w danym momencie każdy człowiek ogólnie zdolny do popełniania przestępstw może być podmiotem danego czynu zabronionego - jeżeli tak, to mamy do czynienia z przestępstwem o charakterze powszechnym, jeżeli nie - indywidualnym, przy czym nie wyróżniamy już tutaj rodzajów przestępstwa indywidualnego; posługujemy się tym pojęciem w jednolitym, szerokim znaczeniu, jako instytucji o opozycyjnym charakterze wobec przestępstw powszechnych.

Oczywiście wskazane podejście do problemu, choć chyba najbardziej właściwe, może budzić pewne wątpliwości. Spójrzmy bowiem np. na przestępstwo wyrabiania materiałów promieniotwórczych stypizowane w art. $184 \S 1 \mathrm{k} . \mathrm{k}$. Ma ono niewątpliwie charakter powszechny, jednak czy każdy z nas może je tak po prostu popełnić? Nie, gdyż do popełnienia tego przestępstwa potrzebna jest specjalistyczna wiedza i specjalistyczny sprzęt, dlatego tė̇ osoba niedysponujaca nimi musiałaby podjacc pewne działania w celu ich zdobycia. Wynika z tego jednak, że w przypadku niewielu przestępstw możliwe jest ich popełnienie bez podjęcia żadnych czynności przygotowawczych. Oznacza to jednak, że do momentu ich podjęcia nie jesteśmy w stanie popełnić danego 
przestępstwa. Czy wynika zatem z tego, że przestępstwo wyrabiania materiałów promieniotwórczych jest jednak przestępstwem indywidualnym, skoro w danym momencie może je popełnić nie każdy, a jedynie osoby dysponujące specjalistyczną wiedzą i sprzętem?

Aby odpowiedzieć na to pytanie, konieczne jest poczynienie pewnej uwagi. Otóż szczególne właściwości podmiotu przestępstwa decydujace o bycie przestępstwa indywidualnego mają charakter w pewien sposób niezależny od samego podmiotu i dotyczą jego relacji ze światem zewnętrznym ${ }^{38}$. Tak np. „matka” odnosi się do dziecka, które posiada; funkcjonariusza publicznego określamy tak ze względu na szczególne funkcje, jakie pełni w społeczeństwie; żołnierza - ze względu na jego przynależność do sił zbrojnych danego kraju, a podmiot określany jako „składający zeznanie” konstytuuje się dopiero w momencie, gdy zostanie wezwany przez są lub podobny organ do ich złożenia (tak więc szczególna cecha sprawcy powstaje jedynie ze względu na jego interferencję ze światem zewnętrznym). Widać tutaj zdecydowaną różnicę w porównaniu z przestępstwem wyrabiania materiałów promieniotwórczych, gdyż w jego przypadku możliwość zostania sprawcą danego przestępstwa zależy wyłącznie od naszej inicjatywy, niezależnej od innych osób. Sami decydujemy bowiem, czy zdobędziemy wiedzę (np. poprzez odpowiednią literaturę czy studia chemiczne) i rozpoczniemy konstrukcję specjalistycznego sprzętu, niezbędnego do popełnienia przestępstwa. Jest to jednak niemal całkowicie od nas zależne, podczas gdy w przypadku przestępstw indywidualnych wystąpienie u danego podmiotu cechy niezbędnej, by być sprawcą danego czynu zabronionego, jest uzależnione od jego relacji ze światem zewnętrznym i dlatego jest ono od niego przynajmniej częściowo niezależne.

Tak więc zgodnie z przedstawionymi wyżej przykładami: matką można zostać jedynie na skutek urodzenia dziecka, co jest jednak w dużej mierze od nas niezależne, ponieważ kobieta nie może mieć pewności co do tego, czy uda jej się zajść w ciążę i urodzić dziecko; funkcjonariusz publiczny musi zostać na taką funkcję powołany, co również nie zależy od niego; żołnierz musi zostać najpierw przyjęty do wojska, a składający zeznania - wezwany do ich złożenia przez sąd. Wynika z tego, że to właśnie w stopniu zależności od świata zewnętrznego wystapienia danej cechy podmiotu, należy doszukiwać się zasadniczej różnicy między przestępstwami indywidualnymi a powszechnymi. Stąd też sformułowany w pierwszej kolejności wymóg, czyli możliwość popełnienia jakiegoś przestępstwa w danym momencie przez wszystkie osoby, powinien zostać zmodyfikowany w ten sposób, że przestępstwo, którego nie moga w danym momencie popełnić wszyscy ludzie ogólnie zdatni do popełnienia czynów zabronionych, jest przestępstwem indywidualnym, chyba że każdy człowiek może podjąć działania zależne przede wszystkim jedynie od siebie, które umożliwią mu zostanie podmiotem tego przestępstwa.

Z powyższego widać więc, że kompleksowe przyjrzenie się piśmiennictwu poświęconemu istocie przestępstw indywidualnych zmusza do przeformułowa-

\footnotetext{
${ }^{38}$ W. Bugajski, op. cit., s. 832.
} 
nia dominujących dotychczas poglądów na ten temat, w szczególności w zakresie samego pojęcia „przestępstwa indywidualne”, ich podziału na przestępstwa indywidualne co do czynu i co do sprawcy oraz podmiotów, które mogą je popełnić. Dotychczasowe rozważania zawarte w doktrynie okazują się bowiem w pewnym zakresie niewystarczające i niezupełnie prawidłowe.

mgr Łukasz Pilarczyk

Uniwersytet im. Adama Mickiewicza w Poznaniu

lukasz.pilarczyk@amu.edu.pl

\section{THE ESSENCE OF INDIVIDUAL CRIMES}

\section{Sum mary}

The purpose of this article is presentation of the exiting studies on the nature of individual crimes and identification of the main attributes of these acts. In the author's opinion this subject matter has been neglected by scholars and therefore needs a more thorough analysis. First, the author points to the inaccuracies concerning the very name this category of prohibited acts has been given, and the abuse of the term 'crime' when referring to those acts. After that, he specifies which types of norms apply to these types of acts. He also describes the differences between individual and common crimes, and draws attention to the considerable heterogeneity of individual crimes, as can be seen from the quantity of various attributes describing the perpetrators of these crimes. The number of classes of prohibited acts that are similar to individual crimes is an additional proof of that variety. The next step is to show the essential differences between prohibited acts and individual crimes, asking a question, though, whether making such distinction makes any sense. Finally, the key issue, which is the specification of the distinctive features differentiating individual crimes, is addressed. These are the features that are primarily responsible for the possibility of committing or not committing of a crime by anyone, which possibility is of a nature independent of the perpetrator, but relative to his relationship with the external world. 
Copyright of Journal of Law, Economics and Sociology is the property of Faculty of Law and Administration of Adam Mickiewicz University in Poznan and its content may not be copied or emailed to multiple sites or posted to a listserv without the copyright holder's express written permission. However, users may print, download, or email articles for individual use.

Właścicielem praw autorskich do „Ruchu Prawniczego, Ekonomicznego i Socjologicznego” jest Wydział Prawa i Administracji Uniwersytetu im. Adama Mickiewicza w Poznaniu. Zawartość czasopisma nie może być kopiowana, przesyłana do innych stron internetowych bądź zamieszczana na blogach bez pisemnej zgody wydawcy. Niemniej artykuły można drukować, kopiować lub przesyłać w formie elektronicznej na własny użytek. 